\title{
Preservation Artifacts and Loss Pattern of Arsenic: A Case Study from Highly Contaminated Location in Central-East India
}

\author{
Piyush Kant Pandey ${ }^{1}$, Hansa Zankyani ${ }^{2}$, Madhurima Pandey ${ }^{2}$ \\ ${ }^{1}$ Bhilai Institute of Technology, Kendri, New Raipur (Chhattisgarh), India; ${ }^{2}$ Centre for Environmental Science \& Engineering, De- \\ partment of Engineering Chemistry, Bhilai Institute of Technology, Durg (Chhattisgarh), India. \\ Email: \{drpiyush_pandey, hansa_zankyani, drmadhurima_pandey\}@yahoo.com
}

Received August 14 ${ }^{\text {th }}, 2011$; revised September 26 ${ }^{\text {th }}, 2011$; accepted November $2^{\text {nd }}, 2011$.

\begin{abstract}
Arsenic is the focus of public attention because of its wider prevalence and toxicity. Proper sampling is important in characterizing toxic water contaminants in the groundwater. The present paper studies aspects of sampling, preservation artifacts, analytical issues etc. in a natural arsenic contaminated groundwater. The samples were collected from arsenic contaminated groundwater at three locations of village Kaudikasa in Rajnandgaon (Chhattisgarh). The standard method of sampling and preservation of arsenic was examined. The permitted sample holding time in this state is 180 days which has been found to be unrealistic on examination. The communication also compares the loss pattern of arsenic in unpreserved samples with samples preserved and kept at $4^{\circ} \mathrm{C}$. It was found that about As losses during holding after preservation were about $0 \%$ in one day, $35 \%$ in seven day, $70 \%$ in fifteen day, and $65 \%$ in thirty days time. Hence, the present recommended method of preservation leads to huge under reporting of As in natural samples. If the pattern of losses observed at the present location exists at other locations then the actual As levels could be much higher than the reported ones.
\end{abstract}

Keywords: Arsenic, Groundwater Contamination, Preservation, Loss Pattern, Chhattisgarh

\section{Introduction}

Arsenic is one of the oldest poisons known to men and its applications throughout history are wide and varied [1]. Arsenic is a problematic and naturally occurring toxic contaminant, which has many chemical species, each with a different toxicity and mobility [2]. A recent study on arsenic toxicity have shown that exposure to arsenic through drinking water has direct effect on the early stages of life when the brain is usually most vulnerable [3]. Yu Chen and colleagues add to the evidence that arsenic in water increases mortality from cardiovascular disease with the findings of their prospective cohort study in Bangladesh [4]. Ingestion of inorganic arsenic in drinking water causes cancer of the skin, bladder, lung, liver, and kidney [5]. Inorganic arsenic species arsenite $[\mathrm{As}(\mathrm{III})]$ and arsenate $[\mathrm{As}(\mathrm{V})]$ predominate in natural water [6]. Organic arsenic species, such as monomethyl arsonate (MMA) and dimethyl arsinate (DMA), are only present at low levels [7]. Inorganic arsenic species include known carcinogens [8]. Of these, As(III) is more toxic than $\operatorname{As}(\mathrm{V})$, while the toxicities of the organic arsenic species have not been fully evaluated [9-11]. Arsenic contamination in groundwater and related diseases affect major parts of Ganga delta down stream of Rajmahal hills in West Bengal, India and other low lying areas in Bangladesh [12-16]. Alluvial areas from USA, Hungary, China, Taiwan and Vietnam are also similarly affected [17-19]. The problem has also been reported from Kaudikasa, district Rajnandgaon, Chhattisgarh [20-23]. Daus et al. (2002) used nitrilotriacetic acid (NTA), hydrochloric acid ( $\mathrm{HCl})$, phosphoric acid $\left(\mathrm{H}_{3} \mathrm{PO}_{4}\right)$, and acetic acid for this procedure [24], and found the best results with 0.01 $\mathrm{mol} / \mathrm{L} \mathrm{H}_{3} \mathrm{PO}_{4}$. A detailed description of the preservation and sampling of groundwater was given in our previous publication [25]. This paper further studies the implications and reports arsenic losses in preserved groundwater samples. Bednar et al. used ethylenedinitrilotetraacetic acid (EDTA), sulfuric acid $\left(\mathrm{H}_{2} \mathrm{SO}_{4}\right)$, nitric acid $\left(\mathrm{HNO}_{3}\right)$, and $\mathrm{HCl}$ to preserve inorganic arsenic species in groundwater and acid mine drainage samples [26]. Arsenic contamination has been acknowledged as a major public 
health issue by the World Health Organisation (WHO) based on its international prevalence; WHO has proclaimed that it requires to be dealt with on an emergency basis [27].

Sampling is an extremely important consideration in properly characterizing groundwater for toxic water contaminants removal. It is a complicated task to analyze the toxic elements in natural water samples as they are present in a low concentration and are subject to a variety of chemical modifications after sampling. Arsenic is the focus of public attention because of its toxicity. Arsenic analysis, its toxicity, and its fate in the environment have been broadly studied, still its blank values, adsorption to sampling materials and pre-concentration of water samples as well as stabilization of arsenic compounds in water samples under field conditions have been very little investigated. Arsenic species are readily transformed in nature by slight changes in conditions. Each species has a different toxicity and mobility. Also, the analytical procedure must be selected carefully because the levels and hydride generation efficiencies of arsenic in different species can vary, even for the same amount of arsenic [28].

Whatever the collection and storage method used, substantial oxidation of arsenic was commonly observed over periods of weeks to several months [29]. The aim of the preservation is to maintain the original concentration of the trace elements and their chemical nature. A proper estimation of the concentration and speciation of the samples is important from the health point of view, where the dose and its chemical species govern the likely effects. A proper estimation of the concentration and speciation is important from the health point of view, where the dose and its chemical species govern the likely effects. Errors associated with the collection and handlings of a sample generally exceed those associated with the analysis [30].

Preservation of groundwater samples aims to retard the biodegradation reactions, precipitation and co-precipitation reactions, hydrolysis reactions, sorption reactions and any other physico-chemical reactions, which may occur in a natural sample. Sample preservation usually involves reducing or increasing $\mathrm{pH}$ by adding an acid or base preservative. The total concentration of inorganic arsenic species must be preserved in the field to eliminate changes caused by metal oxyhydroxide precipitation, photochemical oxidation, and redox reactions. The standard practice for the preservation of metals, except mercury and hexavalent chromium, is the addition of $\mathrm{HNO}_{3}$ until a pH less than 2 is obtained and the sample holding time in this state is 180 days. The recommended sample container is either glass or plastic bottle that is typically polyethylene, polypropylene or polyvinyl chloride [31-34].

Once a sample is taken, the constituents of the sample should be maintained in the same condition as when collected. When it is not possible to analyze collected samples immediately, samples should be preserved properly. Methods of preservation include cooling, $\mathrm{pH}$ control, and chemical addition. The length of time that a constituent in groundwater will remain stable is related to the character of the constituent and the preservation method used.

Arsenic species are readily transformed in nature by slight changes in conditions. Each species has a different toxicity and mobility. Also, the analytical procedure must be selected carefully because the levels and hydride generation efficiencies of arsenic in different species can vary, even for the same amount of arsenic. Based on extensive experimental results in Fe (II)-contaminated challenge water, it was found that EDTA-HAc could be used to preserve the arsenic species for at least 28 days in opaque plastic bottles. Although the alternative preservatives, $\mathrm{H}_{2} \mathrm{SO}_{4}$ and $\mathrm{H}_{3} \mathrm{PO}_{4}$, successfully preserved the original $\mathrm{As}(\mathrm{III}) /(\mathrm{V})$ speciation under some conditions, these preservatives were generally unsuccessful for the desired 28-day period under reducing and oxidizing conditions in the sample $\mathrm{pH}$ range of $6.5-8.4$ and in the presence of 3 $\mathrm{mg} / \mathrm{L} \mathrm{Fe}(\mathrm{II})$ [35].

\section{Materials and Method}

Arsenic contaminated groundwater samples of three locations of Kaudikasa district Rajnandgaon were the sampling sources.

The methods enumerated in Handbook for Sampling and Sample Preservation of Water and Wastewater [36] was adopted for this experiment. The brief detail is provided in Table 1. Two series of samples were taken for every location. The first series was preserved as per the guidelines.

The second series was kept without preservation. While in storage both types of samples were maintained at $4^{\circ} \mathrm{C}$. The onsite As analysis was carried out using As test kit (Merck, Germany). Both ranges (0.02 - $3 \mathrm{mg} / \mathrm{L}$ and $0.1-3 \mathrm{mg} / \mathrm{L}$ ) of the Merckoquant kits were used depending on the expected level of As. Arsenic was analysed in laboratory by hydride generation Atomic Absorption Spectrophotometer (Varian AA 240 FS), Merck certified standard solution and chemicals were used. Double distilled and deionized water was used in the preparation of standard solutions and for dilution of the samples.

\section{Result and Discussion}

The various equilibria occurring in natural waters in- 
Table 1. Required containers, preservation techniques, and holding times.

\begin{tabular}{|c|c|c|c|}
\hline Parameter & Container & Preservative & Maximum Holding Time \\
\hline \multicolumn{4}{|l|}{ Inorganic Tests } \\
\hline Acidity & $P, G$ & $\mathrm{Cool}, 4^{\circ} \mathrm{C}$ & 14 days \\
\hline Alkalinity & $P, G$ & $\mathrm{Cool}, 4^{\circ} \mathrm{C}$ & 14 days \\
\hline BOD & $P, G$ & $\mathrm{Cool}, 4^{\circ} \mathrm{C}$ & 48 hours \\
\hline \multirow{2}{*}{ COD } & \multirow{2}{*}{$\mathrm{P}, \mathrm{G}$} & & \multirow{2}{*}{28 days } \\
\hline & & $\mathrm{H}_{2} \mathrm{SO}_{4}$ to $\mathrm{pH}<2$ & \\
\hline Hardness & $P, G$ & $\mathrm{HNO}_{3}$ to $\mathrm{pH}<2$ & 6 months \\
\hline Hydrogen ion (pH) & $\mathrm{P}, \mathrm{G}$ & None required & Analyze immediately \\
\hline \multicolumn{4}{|l|}{ Metals } \\
\hline Chromium (VI) & $P, G$ & $\mathrm{Cool}, 4^{\circ} \mathrm{C}$ & 24 hours \\
\hline Mercury & $P, G$ & $\mathrm{HNO}_{3}$ to $\mathrm{pH}<2$ & 28 days \\
\hline Metals, except above & $P, G$ & $\mathrm{HNO}_{3}$ to $\mathrm{pH}<2$ & 6 months \\
\hline Residue, non-filterable (TSS) & $P, G$ & $\mathrm{Cool}, 4^{\circ} \mathrm{C}$ & 7 days \\
\hline Residue, settleable & $P, G$ & $\mathrm{Cool}, 4^{\circ} \mathrm{C}$ & 48 hours \\
\hline Residue, volatile & $P, G$ & $\mathrm{Cool}, 4^{\circ} \mathrm{C}$ & 7 days \\
\hline
\end{tabular}

Adopted from Environmental Protection Agency Guidelines for handling and preserving samples. $P=$ plastic, $G=$ glass.

volving metal ions make the sample preservation critical, as changes between arsenate and arsenite can be caused by bacterial activity, as well as by oxidising or reducing components in the natural water. In general, the addition of acids has been recommended for natural water preservation [37] but this procedure can not be used for arsenic speciation, as it would affect the arsenic forms present.

The three locations of village Kaudikasa district Rajnandgaon were analysed. The samples were first analysed on site by As testing kit and thereafter in laboratory at specified time intervals. Each and every sample of Location I, Location II and Location III were analyzed 4 times after preservation that is first day, seventh day, fifteenth day and thirtieth day. Triplicate analyses, for each particular sample, were performed. In Figure 1 the As concentration in preserved and unpreserved samples of all three Locations is shown. The Location II shows the maximum loss of As concentration in comparison to Location I and III.

The results further show that the concentration of As decreases with the time and after some days it becomes constant. However, on the first day after sampling no significant losses of As concentration was observed. Then, the rate of loss of As increased with holding time. The maximum loss was observed within first 7 days. The rate of loss was positive till $15^{\text {th }}$ day and then no significant loss was observed till 30 $0^{\text {th }}$ day (Figures 2, 3 and 4). The total percentage loss of arsenic samples of Location I, Location II and Location III of groundwater, collected from Kaudikasa is shown in Figure 5.

Overall taking all three locations together the average percentage loss of As was $0 \%$ in one day, 35\% in seven day, $70 \%$ in fifteen day, and $65 \%$ in thirty days time Table 2 . Individually the Location II showed more prominent loss pattern compared to the other two locations. This means that As losses are expected to be more rapid in case of higher As values. This observation is very significant because in the As studies worldwide, the As concentrations are generally believed to be more or less stable and are expected to follow a law of average. Looking to this trend monitored at Kaudikasa we are inclined to say that the reported results may not be really reflecting the true picture of As contamination. It is because of the fact in the most studies the sample holding time is neither specified nor mentioned in the results. In many cases the actual analysis might be performed very late after the sampling. We are further inclined to say that many of the reported results could be $60 \%-70 \%$ less than the actual. If this is the case then we have to realize that we are dealing with a monster which is more powerful than what we believe. To effectively deal with such a condition it is necessary that the proper sampling, time specified preservation and analysis regime is necessary. 


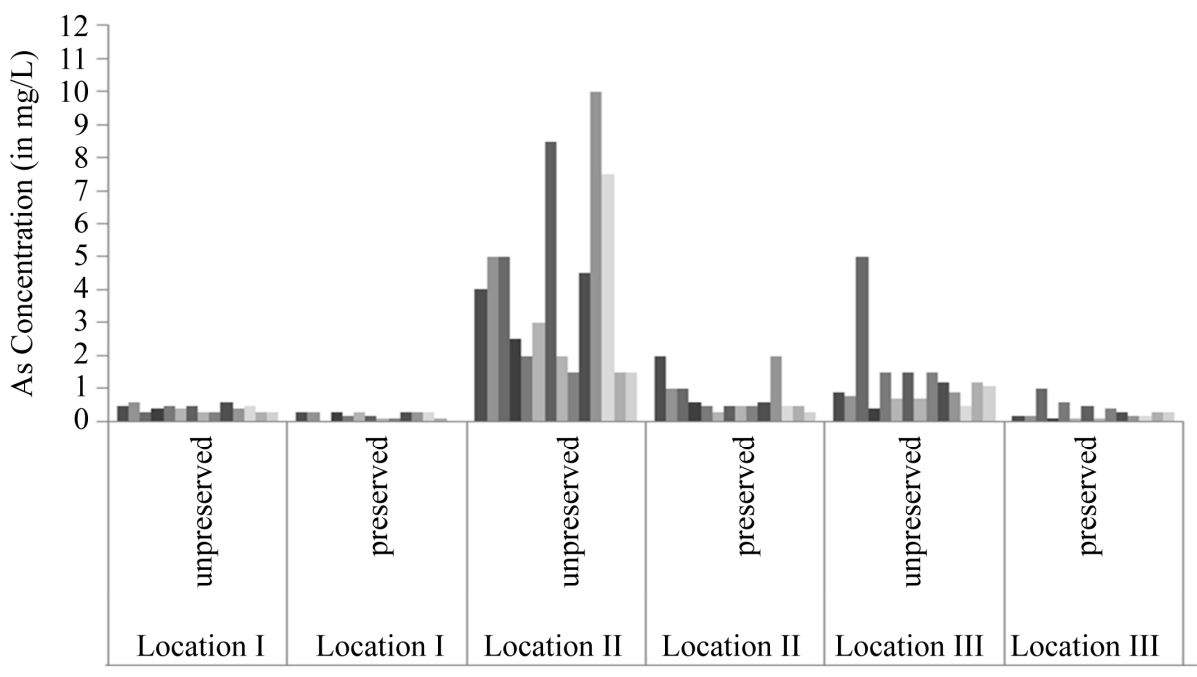

Figure 1. Arsenic loss (mg/L) pattern of three Locations during the holding time of one month.

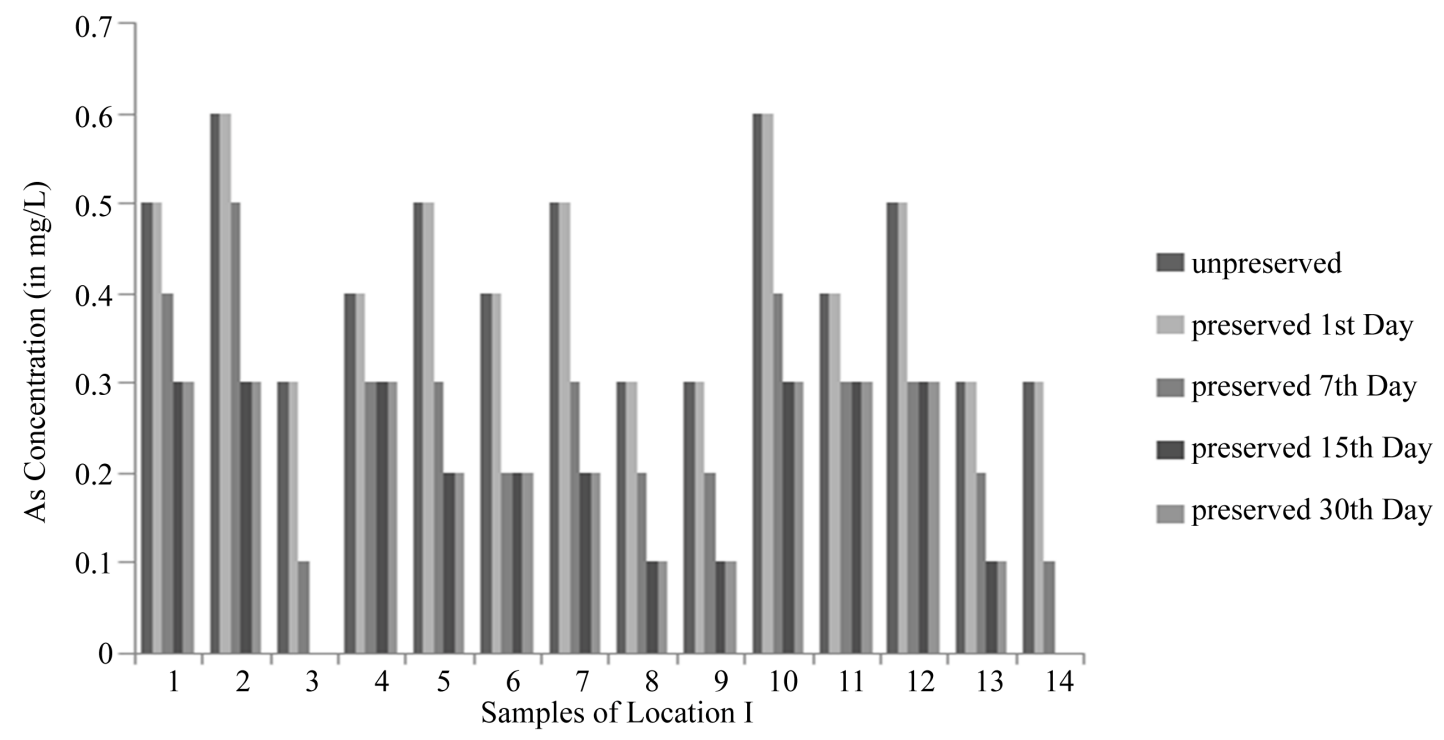

Figure 2. Arsenic loss (mg/L) pattern of Location I during specified time intervals.

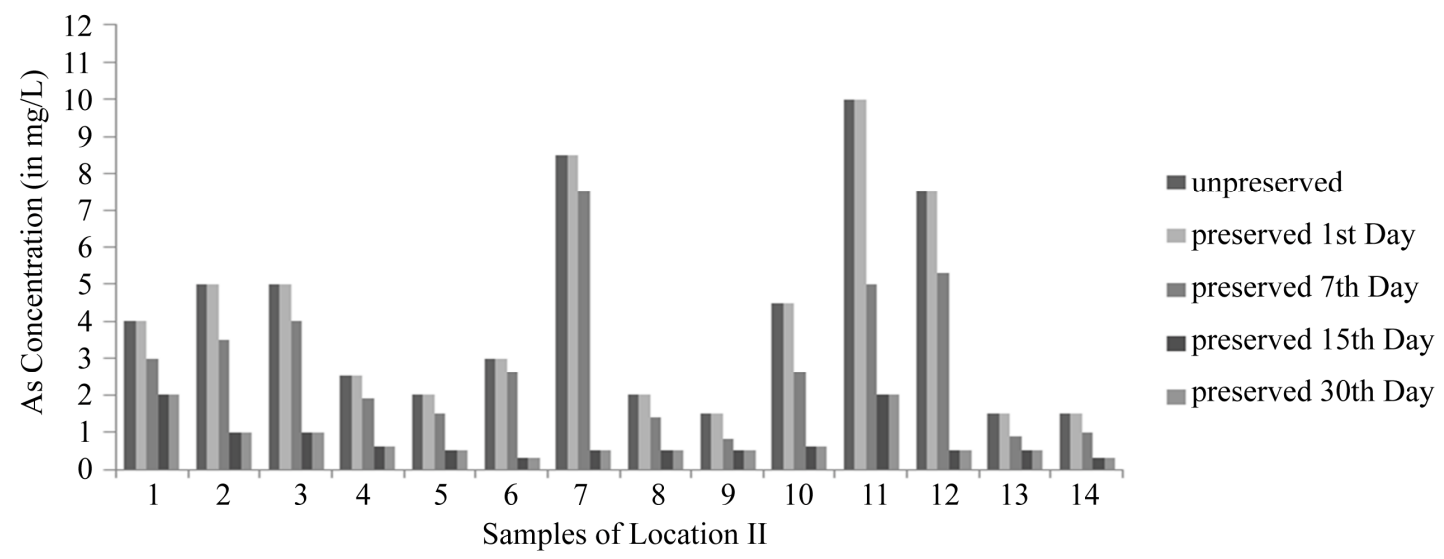

Figure 3. Arsenic loss (mg/L) pattern of Location II during specified time intervals. 




Figure 4. Arsenic loss (mg/L) pattern of Location III during specified time intervals.

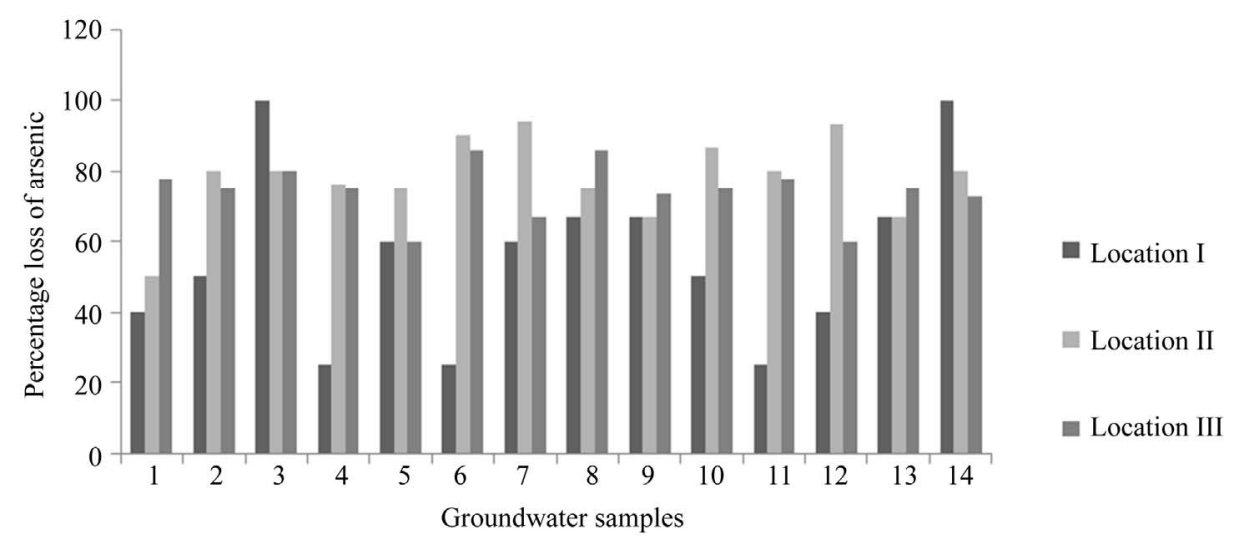

Figure 5. Percentage loss of Arsenic at three Locations.

Table 2. Average percentage loss of Arsenic at three locations at different time intervals.

\begin{tabular}{|c|c|c|c|c|}
\hline & $1^{\text {st }}$ Day & $7^{\text {th }}$ Day & $15^{\text {th }}$ Day & $30^{\text {th }}$ Day \\
\hline Location I & 0 & 37 & 57 & 55 \\
\hline Location II & 0 & 30 & 78 & 73 \\
\hline Location III & 0 & 39 & 74 & 67 \\
\hline Overall Loss pattern & $\mathbf{0}$ & 35 & 70 & 65 \\
\hline
\end{tabular}

Further the study on sampling and preservation artifact at all major As contaminated locations it should be carried out immediately.

Our work has found that the As contaminated levels at Kaudikasa village are still heavily contaminated [25]. Table 3 presents the comparison of reported yearly mean values of arsenic levels of three years i.e. 1999, 2000 [25] and 2008 [38]. Here we find the difference in levels reported. The reason for this difference could be either a genuine geo-chemical reason or could simply be due to the preservation artifacts. In either case a more careful and stringent QA/QC is called for.

As far as the reason of such losses is concerned we had hypothesized that the loss of arsenic may be due to the conversion of arsenic groundwater samples to the volatile phase [25]. Based on this sequel study the probable loss in polyethylene bottles due to conversion of As to volatile phase appears valid. It is because we have also found less As losses when the glass bottles were used as sample container. 
Table 3. Comparison of reported arsenic levels from the same locations in Kaudikasa village.

\begin{tabular}{ccccccc}
\hline Location & Identifying number & Area & $\begin{array}{c}\text { Mean arsenic }(\mu \mathrm{g} / \mathrm{L}) \\
2008\end{array}$ & $\begin{array}{c}\text { Mean arsenic }(\mu \mathrm{g} / \mathrm{L}) \\
2000\end{array}$ & $\begin{array}{c}\text { Mean arsenic } \\
(\mu \mathrm{g} / \mathrm{L}) ~ 1999\end{array}$ & $\begin{array}{c}\text { Total arsenic }(\mu \mathrm{g} / \mathrm{L}) \\
(\mathrm{NEERI})\end{array}$ \\
\hline Location I & HP 9 & Anganbadi & 462 & 1120 & 960 & 826 \\
Location II & HP 6 & Kunjam House & 2817 & 3050 & 1965 & 1890 \\
Location III & HP 12 & Old Boys Hostel & 966 & 1265 & 300 & 245 \\
\hline
\end{tabular}

NEERI, 2000, Study of arsenic contamination in the groundwater of Block Chowki, District Rajnandgaon (MP), National Environment Engineering Research Institute, Nagpur.

\section{Conclusions}

Analytically, the nature of arsenic compounds present and other concomitant parameters in the contaminated samples in Kaudikasa village need a further study to explain the higher rates of arsenic loss compared to the synthetic samples or similar samples from different locations. The results also show that the sampling and preservation artifacts may result into serious under-reporting of arsenic levels, particularly in developing countries.

It is suggested that many of the reported results around the world could be $60 \%$ - $70 \%$ less than the actual. If this is the case then the arsenic monster is more powerful than what we believe. To effectively deal with such a condition it is necessary that the proper sampling, time specified preservation and analysis regime may be followed. Further the study on sampling and preservation artifact at all major As contaminated locations it should be carried out immediately and the results be interpreted accordingly.

The reason for the loss of As after sampling appears to be due to the conversion of soluble As into volatile species which could permeate out more easily in polyethylene bottles than the glass one.

\section{REFERENCES}

[1] A. Vahidnia, G. B. Van der Voet and F. A. De Wolff, "Arsenic Neurotoxicity-A Review," Human and Experimental Toxicology, Vol. 26, No. 10, 2007, pp. 823832. doi:10.1177/0960327107084539

[2] B. K. Mandal and K. T. Suzuki, "Arsenic Round the World: A Review,” Talanta, Vol. 58, No. 1, 2002, pp. 201-235. doi:10.1016/S0039-9140(02)00268-0

[3] J. D. Hamadani, S. M. G. Mcgregor, F. Tofail, B. Nermell and B. Fangstrom Elfo'l, "Pre and Postnatal Arsenic Exposure and Child Developments at 18 Months of Age: A Cohort Study in Rural Bangladesh,” International Journal of Epidemiology, Vol. 39, No. 5, 2010, pp. 1206-1216.

[4] Y. Chen, J. H. Graziano, F. Parvez, M. Liu, V. Slavkovich and T. Kalra, "Arsenic Exposure from Drinking Water and Mortality from Cardiovascular Disease in Bangladesh: Prospective Cohort Study,” British Medical
Journal, Vol. 362, 2011, p. d2431.

doi:10.1136/bmj.d2431

[5] Y. Yuan, G. Marshall, C. Ferreccio, C. Steinmaus, S. Selvin and J. Liaw, "Kidney Cancer Mortality: Fifty-Year Latency Patterns Related to Arsenic Exposure,” Epidemiology, Vol. 21, No. 1, 2010, pp. 103-108. doi:10.1097/EDE.0b013e3181c21e46

[6] J. A. Plant, D. G. Kinniburgh, P. L. Smedley, F. M. Fordyce and B. A. Klinck, “Arsenic and Selenium," Environmental Geochemistry, Vol. 33, 2005.

[7] A. J. Bednar, J. R. Garbarino, M. R. Burkhardt, J. F. Ranville and T. R. Wildeman, "Field and Laboratory Arsenic Speciation Methods and Their Application to Natural Water Analysis," Water Research, Vol. 38, No. 2, 2004, pp. 355-364. doi:10.1016/j.watres.2003.09.034

[8] USEPA, IRIS, CASRN 7440-38-2, accessed in June 2006.

[9] D. J. Thomas, M. Styblo and S. Lin, "The Cellular Metabolism and Systemic Toxicity of Arsenic,” Toxicology and Applied Pharmacology, Vol. 176, No. 2, 2001, pp. 127-144. doi:10.1006/taap.2001.9258

[10] M. F. Hughes, “Arsenic Toxicity and Potential Mechanisms of Action,” Toxicology Letters, Vol. 133, No. 1, 2002, pp. 1-16. doi:10.1016/S0378-4274(02)00084-X

[11] H. V. Aposhian, R. A. Zakharyan, M. D. Avram, M. J. Kopplin and M. L. Wollenberg, "Oxidation and Detoxification of Trivalent Arsenic Species,” Toxicology and Applied Pharmacology, Vol. 193, No. 1, 2003, pp. 1-8. doi:10.1016/S0041-008X(03)00324-7

[12] D. Das, G. Samanta, B. K. Mandal, T. Roy Chowdhury, C. R. Chanda, P. P. Chowdhury, G. K. Basu and D. Chakraborti, "Arsenic in Groundwater in Six Districts of West Bengal, India,” Environmental Geochemistry and Health, Vol. 18, No. 1, 1996, pp. 5-15. doi:10.1007/BF01757214

[13] B. K. Mandal, T. R. Chowdhury, G. Samanta, G. K. Basu, P. P. Chowdhury, C. R. Chanda, D. Lodh, N. K. Karan, R. K. Dhar, D. K. Tamili, D. Das, K. C. Saha and D. Chakraborti, "Arsenic in Groundwater in Seven Districts of West Bengal, India-The Biggest Arsenic Calamity in the World,” Current Science, Vol. 70, 1996, pp. 976-986.

[14] S. Mallick and N. R. Rajagopal, "Groundwater Development in the Arsenic Affected Alluvial Belt of West Bengal-Some Questions,” Current Science, Vol. 70, No. 11, 1996, pp. 956-958. 
[15] R. T. Nickson, J. M. McArthur and P Ravenscroft, "Mechanism of Arsenic Release to Groundwater, Bangladesh and West Bengal,” Applied Geochemistry, Vol. 15, No. 4, 2000, pp. 403-413. doi:10.1016/S0883-2927(99)00086-4

[16] Anonym, Main Report, Govt. of Bangladesh, British Geological Survey and Mott Macdonald, UK, 1999.

[17] L. Wang and J. Huang, "Arsenic in the Environment, Part II,” In: J. O. Nriagu, Ed., Human Health and Ecosystem Effects, John Wiley \& Sons, Inc., New York, 1994, pp. 159-172.

[18] P. L. Smedley, W. M. Edmunds and K. B. Pelig-ba, In: J. D. Applaton, R. Fuge and G. J. H. McCall, Eds., Environmental Geochemistry and Health, Geol. Soc. London Spec. Publ, 2000, Vol. 113, pp. 163-182.

[19] A. H. Welch, D. B. Westjohn, D. R. Helsel and R. B. Wanty, "Arsenic in Groundwater of the United StatesOccurrence and Geochemistry," Ground Water, Vol. 38, No. 4, 2000, pp. 589-604. doi:10.1111/j.1745-6584.2000.tb00251.x

[20] D. Chakraborti, B. K. Biswas, T. R. Chowdhury, G. K. Basu, B. K. Mandal, U. K. Chowdhury, S. C. Mukherjee, J. P. Gupta, S. R. Chowdhry and K. C. Rathore, “Arsenic Groundwater Contamination and Sufferings of People in Rajnandgaon Districts, Madhya Pradesh, India,” Current science, Vol. 77, No. 4, 1999, pp. 502-504.

[21] P. K. Pandey, R. N. Khare, R. Sharma, S. K. Sar, M. Pandey and P. Binayake, "Arsenicosis and Deteriorating Ground Water Quality; Unfolding Crisis in Central East Indian Region,” Current Science, Vol. 77, 1999, pp. 686693.

[22] Anonym, News, Geological Survey of India, Vol. 18, 2001, pp. 21-22.

[23] S. K. Acharyya, I. D. Ashyiya, Y. Pandey, S. Lahiri, V. W. Khangan and S. K. Sarkar, in National Symposium on Role of Earth Sciences in Integrated Development and Related Societal Issues, Geological Survey of India, Vol. 65, 2001, pp. 7-18.

[24] B. Daus, J. Mattusch, R. Wennrich and H. Weiss, "Investigation on Stability and Preservation of Arsenic Species in Iron-Rich Water Samples,” Talanta, Vol. 58, No. 1, 2002, pp. 57-65. doi:10.1016/S0039-9140(02)00256-4

[25] P. K. Pandey, S. Yadav, S. Nair and M. Pandey, "Sampling and Preservation Artifacts in Arsenic Analysis: Implications for Public Health Issues in Developing Countries,” Current Science, Vol. 86, 2004, pp. 14261432.
[26] A. J. Bednar, J. R. Garbarino, J. F. Ranville and T. R. Wildeman, "Preserving the Distribution of Inorganic Arsenic Species in Groundwater and Acid Mine Drainage Samples,” Environmental Science and Technology, Vol. 36, 2002, pp. 2213-2218. doi:10.1021/es0157651

[27] World Health Organisation (WHO), "Fact Sheet No 210," Geneva, 1999.

[28] Y. T. Kim, H. Yoon, C. Yoon and N. C. Woo, “An Assessment of Sampling, Preservation, and Analytical Procedures for Arsenic Speciation in Potentially Contaminated Waters," Environmental Geochemistry and Health, Vol. 29, No. 4, 2007, pp. 337-346.

[29] H. A. L. Rowland, A. G. Gault, J. M. Charnock and D. A. Polya, "Preservation and XANES Determination of the Oxidation State of Solid-Phase Arsenic in Shallow Sedimentary Aquifers in Bengal and Cambodia," Mineralogical Magazine, Vol. 69, No. 5, 2005, pp. 825-839. doi:10.1180/0026461056950291

[30] R. W. Puls and J. B. Michael, "Low-Flow (Minimal Drawdown) Ground-Water Sampling Procedures," EPA Groundwater Issue, US EPA, Vol. 540, S-95, 1996, p. 504.

[31] APHA, "Standards Methods for the Examination of Water and Wastewater," American Public Health Association, Washington DC, 1992.

[32] APHA, "Standards Methods for the Examination of Water and Wastewater," American Public Health Association, Washington DC, 1995.

[33] US EPA, “Rules and Regulations,” US Environmental Protection Agency, Federal Register 49, No. 209, USA, 1984.

[34] WDNR, “Groundwater Sampling Field Manual,” Wisconsin Department of Natural Resources PUBL-DG-038 96, WDNR, USA, 1996.

[35] D. A. Clifford and G. Samanta, "Preservation of Arsenic Species,” AWWARF Report 91117F, 2007, 148 Pages.

[36] EPA, "The Handbook for SAMPLING and Sample Preservation of Water and Wastewater," EPA Number600482029, 1982.

[37] T. A. Hinners, "Arsenic Speciation: Limitations with Direct Hydride Analysis,” Analyst, Vol. 105, 1980, pp. 751-755. doi:10.1039/an9800500751

[38] P. K. Pandey, H. Zankyani, R. Deshmukh and M. Pandey, "Arsenic Contamination in Central-East India: New Lessons for the Environmental Health," International Journal of Environmental Studies, in Press, 2012. 